DOMESTICATING ORGAN TRANSPLANT 
This page intentionally left blank 


\title{
Domesticating Organ Transplant
}

\author{
FAMILIAL SACRIFICE
}

AND

NATIONAL ASPIRATION

IN MEXICO

MEGAN CROWLEY-MATOKA 
(ㄷ) 2016 Duke University Press

All rights reserved

Printed in the United States of America on acid-free paper $\infty$

Typeset in Quadraat Pro by Westchester Book Group

Library of Congress Cataloging-in-Publication Data

Crowley-Matoka, Megan, [date] author.

Domesticating organ transplant : familial sacrifice and national

aspiration in Mexico / Megan Crowley-Matoka.

pages $\mathrm{cm}$

Includes bibliographical references and index.

ISBN 978-o-8223-6052-o (hardcover : alk. paper)

ISBN 978-o-8223-6o67-4 (pbk. : alk. paper)

ISBN 978-o-8223-7463-3 (e-book)

I. Kidneys-Transplantation-Mexico. 2. Organ donors-Mexico.

3. Transplantation of organs, tissues, etc.-Social aspects-Mexico.

4. Transplantation of organs, tissues, etc.-Moral and

ethical aspects. I. Title.

RD575.C77 2016

$617.4^{\prime} 610592-\mathrm{dc} 23$

2015031550

Cover art: Collage by Martyn Schmoll; heart photo ๑ Eduard

Lysenko, istock; locket photo $\odot$ juicybits, istock. 


\section{For my father, James Swenney Crowley}

And my mentor, Arthur J. Rubel

Their lively intellects and love of debate are dearly missed 
This page intentionally left blank 